\title{
The concept of migratory emergency in territorial and urban planning: analysis of the Spanish Mediterranean coast
}

Abstract: Throughout 2020, the increase in arrivals of irregular migrants by sea has, in some cases, led to overcrowding on the coasts or in ports. This has made it necessary to rethink the reception cities to adapt them to a new space demand that satisfies border management. The main objective of this study is to reflect on the concept of emergency and planning in the territory, which is why it has been analyzed four cases of study on the Mediterranean coast, one of the most dangerous access routes at present.

Keywords: immigration; emergency settlement; territory; foreigners' temporary stay centres

Citation: Enciso, E., 2022, The concept of migratory emergency in territorial and urban planning: analysis of the Spanish Mediterranean coast. SUPTM 2022 conference proceedings sciforum-054333.

https://doi.org/10.31428/10317/10491

Publisher's Note: UPCT and Sciforum stays neutral with regard to jurisdictional claims in published maps and institutional affiliations.

Copyright: (C) 2022 by the authors. Submitted for possible open access publication under the terms and conditions of the Creative Commons Attribution (CC BY) license (https://creativecommons.org/license s/by/4.0/).

\section{Introduction}

In recent years, the number of irregular migrants detected on the Western Mediterranean route has increased significantly, stretching across the sea between Spain and Morocco [1]. During 2020 the Western African route increased 355\% over last year [2]. This situation caused decision from the Spanish government to throw more resources, including the construction of emergency centres. These spots provide first humanitarian assistance and identification at border crossing during a maximum of 72 hours [3]. In order to understand the current migratory situation in Europe, the following figure 1 shows a map with the number of irregular border crossings in 2021, from January to October. Each circle represents one of the main migratory routes. The size of the circle depends on the number of arrivals.
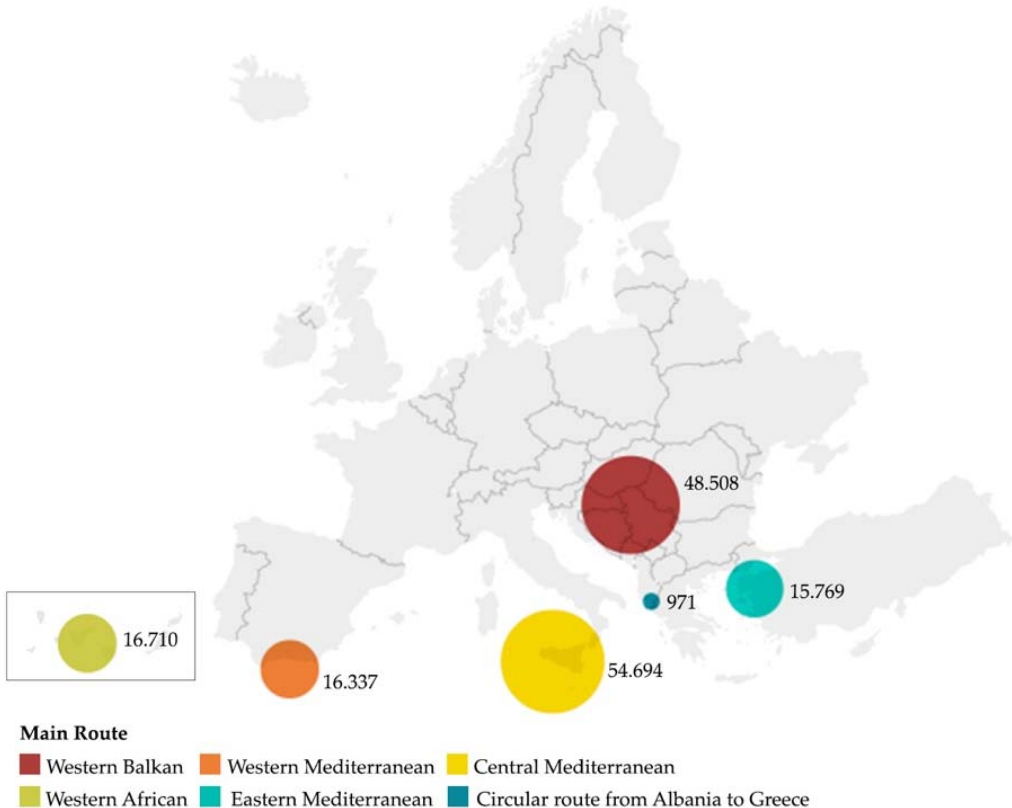

Figure 1. Map with the number of irregular border crossings in Europe during 2020, from January to October. Data provided by FRONTEX and made using the Datawrapper tool. 
The location of most of the emergency Spanish settlements, called foreigners' temporary stay centres, are being concentrated along the Andalusian coast, in maritime ports. Co-financed by EU funds, three new centres have been built through an Emergency Action Plan framework in Malaga, Almeria, and Granada, in conjunction with the consolidation of the already installed in Cadiz [4]. At the European level, these centres can be compared to the hotspots in Greece or Italy [3]. Both can be defined as sites and mechanisms of sorting and identification in critical border spots, which on the one hand offer humanitarian aid and international protection and on the other hand determine rejection and deportation. They also share the lack of a legal framework to rely on. It has been cases of non-compliance with fundamental rights, such as undignified living conditions, leading to situations of chaos and insecurity [5].

\section{Area of study}

Four case studies are proposed for analysis, corresponding to the new emergency settlement created in Malaga, Almeria, Granada, and Cadiz, to draw conclusions and similarities in decision-making. All of them are located in ports, with independent port authorities, and the national police manage them. Figure 2 shows the map of Spain with its location.

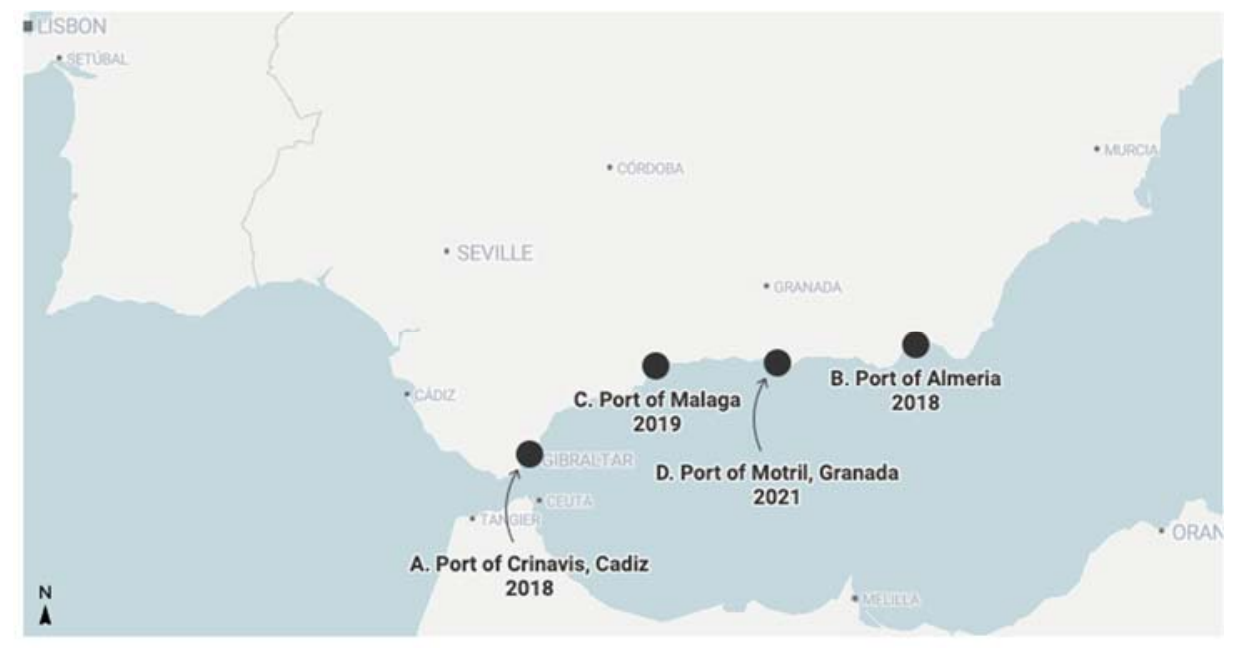

Figure 2. Map of Spain made using the Datawrapper tool that shows the cases of study.

\section{Methodology}

The qualitative methodology was based on case study factsheets to analyze in-depth the following parameters:

1. Social parameters: habitant $/ \mathrm{Km}^{2}, \%$ foreign population, $\%$ ageing population, and $\%$ and middle-income/habitant;

2. Territorial parameters: city planning, main activity, and environment;

3. Architectural parameters: total capacity, year of construction, typology, and reference measure.

The content of the sheets was drafted together with aerial photographs from Google Earth that show the exact location, shape, and control access to the emergency spot. For social parameters, the data was provided publicly by the Andalusian Institute of Sadistic and Cartography [6]. For territorial parameters, the weather data [7] and urban development plans of each city were looked at by the City Council website and port reports. For architectural parameters, since there are no documents about the construction and interior spaces of the settlements, the search for their location, shape and other relative information was based on an analysis of local and national news $[8,9]$. 


\section{Results}

Figure 3 below shows the aerial photographs of the four cases studies. They all are located in port areas, so their perimeter, and therefore their jurisdiction, has been highlighted with a blue line. The control accesses show the ways to get in the area of an emergency spot, including the docks for the maritime vessel. All emergency centres are fenced around their perimeter.

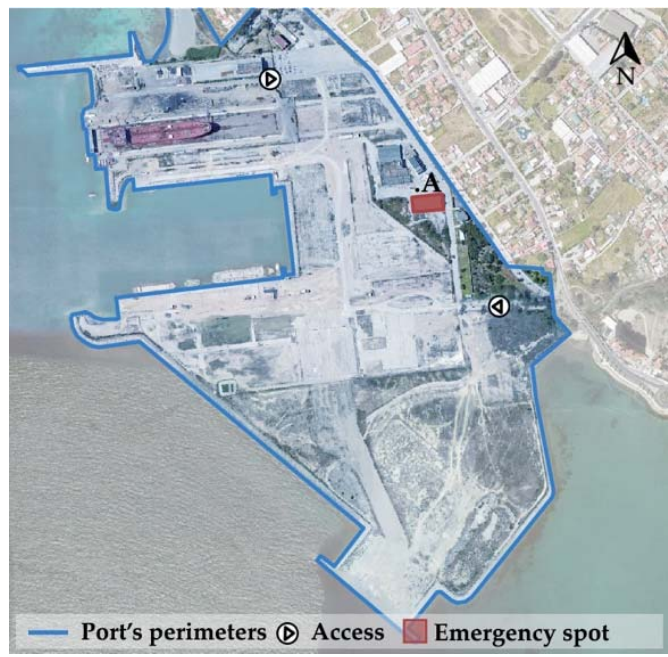

(a)

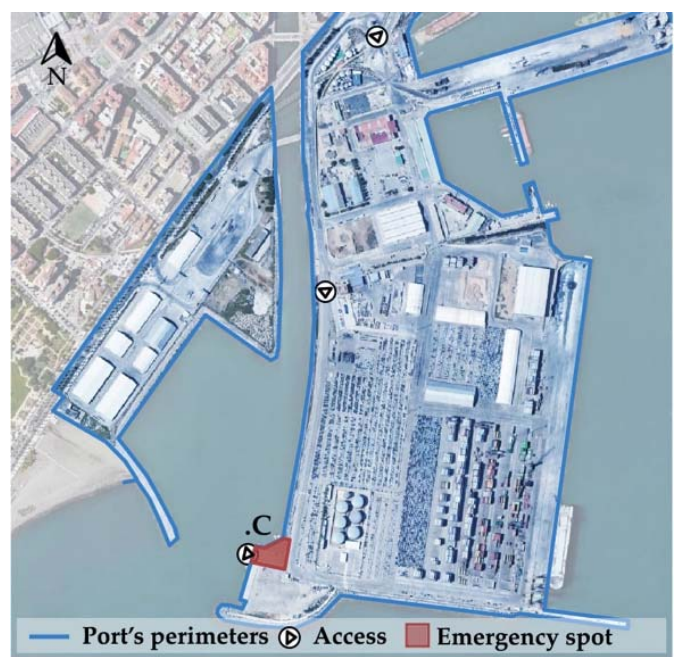

(c)

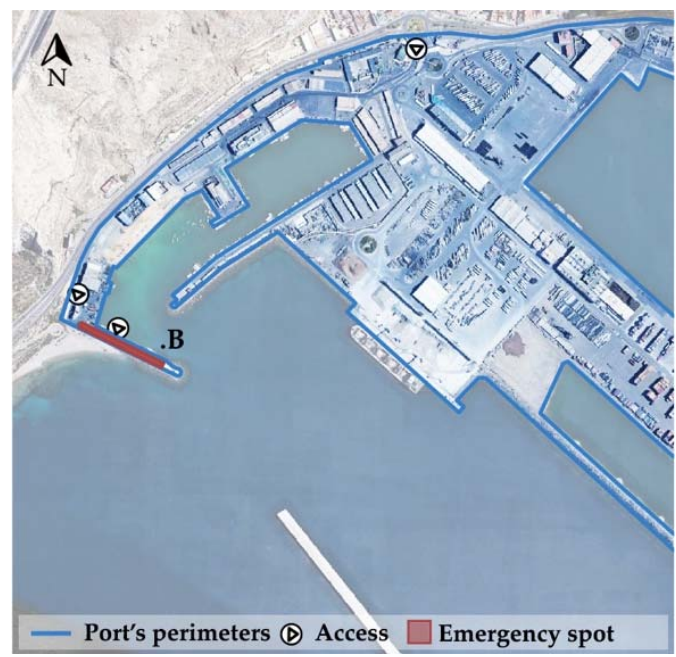

(b)

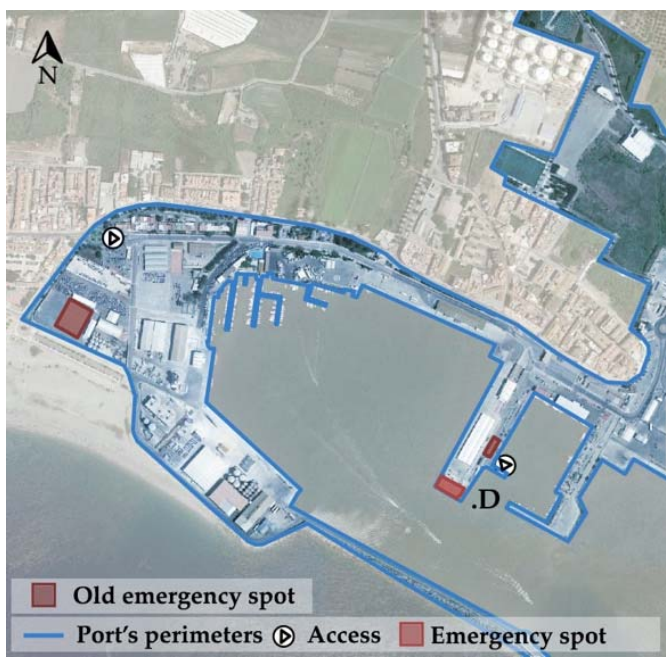

(d)

Figure 3. Aerial photographs of the four cases of study. They are ordered by year of consolidation, from the first to last. (a) Crinavis, Cadiz; (b) Almeria; (c) Malaga; (d) Motril, Granada.

(a) Case of study A: Port of Crinavis, Cadiz, Spain

- Habitants/Km²: 214; Foreign population: 30,3\%; Ageing population: 14,9\%; Middleincome/habitant: 2.062 EUR.

- City planning: communication and transport equipment; Main activity: commercial and industrial; Annual middle-temperature: max. 28C으 - min. 10 $\mathrm{C}^{\mathrm{o}}$

- Total capacity: 600; Year of construction: 2018; Space: Abandoned industrial pavilion; Reference measure: $1871 \mathrm{~m}^{2}$

(b) Case of study B: Port of Almeria, Spain

- Habitants/Km²: 681; Foreign population: 52,5\%; Ageing population: 16,3\%; Middleincome/habitant: 928 EUR. 
- City planning: communication and transport equipment; Main activity: sporting 1 commercial and fishing; Annual middle-temperature: max. 30 $\mathrm{C}^{\mathrm{o}}-\min .8 \mathrm{C}^{\mathrm{o}} \quad 2$

- Total capacity: 230; Year of construction: 2018; Space: Prefabricated standard mod- 3 ules; Reference measure: n/a

(c) Case of study C: Port of Malaga, Spain

- Habitants/Km²: 1.464; Foreign population: 19,5\%; Ageing population: 17,9\%; Middleincome/habitant: 1.166 EUR.

- City planning: communication and transport equipment; Main activity: touristic and

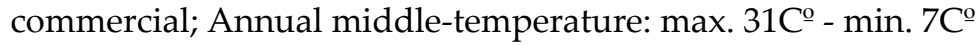

- Total capacity: 300; Year of construction: 2019; Space: Prefabricated standard modules; Reference measure: $2,4 \mathrm{~m}^{2} /$ person

(d) Case of study D: Port of Motril, Granada, Spain

- Habitants/Km²: 567; Foreign population: 36,5\%; Ageing population: 15,4\%; Middleincome/habitant: 1.126 EUR.

- City planning: communication and transport equipment; Main activity: commercial and fishing; Annual middle-temperature: max. $31 \mathrm{C}^{\mathrm{o}}-\min .8 \mathrm{C}^{\mathrm{o}}$

- Total capacity: 200; Year of construction: 2021; Space: Prefabricated standard modules; Reference measure: n/a

\section{Conclusion}

After the analysis, the concept of migration emergency on the Mediterranean coast is distant from the provision of humanitarian aid. It is more closely linked to criteria of surveillance control in border areas. This means that the chosen environment is not the most suitable for vulnerable migrants, such as children, because of the adverse weather conditions near the coast and because the design and materiality aggravate these circumstances. Moreover, in the case of Malaga, the center is located at the mouth of the Guadalmedina river, which is an area of potential flooding. In all the cases, there is a common denominator, which is their location in the most remote areas. This makes emergency migration spaces difficult to access, along with the lack of open information or documents, arouses a feeling of ignorance around the population. They are invisible spaces for the territory.

Funding: This research received no external funding

Conflicts of Interest: The authors declare no conflict of interest

\section{References}

1. Migratory Map, FRONTEX. Available online: https://frontex.europa.eu/we-know/migratory-map/ (accessed on 24 November 2021).

2. Informe Quincenal sobre Inmigración Irregular desde 1 de Enero hasta 31 de diciembre 2020, Ministerio del Interior, Gobierno de España. Available online: http://www.interior.gob.es/prensa/balances-e-informes/2020 (accessed on 24 November 2021).

3. Iker, B. The Foreigners' Temporary Stay Centres as the new model of migration control: current situation legal (de)regulation and mechanisms of control and guarantee of rights. DERECHOS Y LIBERTADES, 2021, No. 45, 267-302. DOI: https://doi.org/10.20318/dyl.2021.6108

4. Acciones de emergencias 2018, 2019 y 2020, Ministerio del Interior, Gobierno de España. Available online: http://www.interior.gob.es/documents/642012/13313549/FSI+EMAS+2018_19+2021.pdf/3aebac14-1ad4-48b7-911d-e12bd70fd9c8 (accessed on 19 November 2021).

5. Leonie, A.; Sergio, C.; Elspeth G. Documenting the Migration Crisis in the Mediterranean Spaces of Transit, Migration Management and Migrant Agency. CEPS Liberty and Security in Europe, 2016, No. 94, 4-5

6. Instituto de Estadística y Cartografía de Andalucía, Junta de Andalucía. Available online: https://www.juntadeandalucia.es/institutodeestadisticaycartografia/sima/provincia.htm?prov=29 (accessed on 3 December 2021).

7. Temperature Data. Weather Spark. Available online: https://es.weatherspark.com/ (accessed on 3 December 2021).

8. elpais.es. Available online: https://elpais.com/elpais/2018/12/28/album/1545985445 421788.html\#foto_gal_1 (accessed on 3 December 2021).

9. eldiario.es. Available online https://www.eldiario.es/desalambre/gobierno-destinara-calabozos-malagaretenidos 1 1433396.html (accessed on 30 November 2021) 